\title{
Short communication: Intestinal digestibility of amino acids in fluid- and particle-associated rumen bacteria determined using a precision-fed cecectomized rooster bioassay
}

\author{
A. C. Fonseca, ${ }^{*}$ S. M. Fredin, ${ }^{*}$ L. F. Ferraretto, ${ }^{*}$ C. M. Parsons, $†$ P. L. Utterback, $†$ and R. D. Shaver ${ }^{* 1}$ \\ ${ }^{*}$ Department of Dairy Science, University of Wisconsin, Madison 53706 \\ †Department of Animal Science, University of Illinois, Urbana-Champaign 61801
}

\begin{abstract}
Microbial protein represents the majority of metabolizable protein absorbed by ruminant animals. Enhanced understanding of the AA digestibility of rumen microbes will improve estimates of metabolizable protein. The objective of this experiment was to determine the digestibility of AA in fluid- (FAB) and particle-associated bacteria (PAB) using the precisionfed cecectomized rooster bioassay. Bacteria were isolated from 4 ruminally cannulated lactating Holstein cows by differential centrifugation, including particle suspension in $0.1 \%$ Tween- 80 for increased removal of PAB from ruminal digesta. Samples of FAB and PAB were fed to 9 cecectomized roosters to determine standardized digestibility of AA. Total AA digestibility was 76.8 and $75.5 \%$ for $\mathrm{FAB}$ and $\mathrm{PAB}$, respectively, but did not differ. Differences existed in AA digestibilities within bacterial type when compared with the mean essential AA digestibility value. Compared with previous literature estimates of AA digestibility in microbes $($ mean $=76 \%$; range $=57-87 \%)$ and relative to National Research Council estimates of total AA from rumen bacteria ( $80 \%$ ), the precision-fed cecectomized rooster assay is an acceptable in vivo model to determine AA digestibility of rumen bacteria.
\end{abstract}

Key words: digestibility, rumen bacteria

\section{Short Communication}

Ruminally synthesized microbial protein typically supplies most of the AA flowing to the small intestine of dairy cows (Clark et al., 1992), and most of the microbes flowing to the small intestine are of bacterial origin (NRC, 2001). The NRC (2001) assumes that microbial protein is $80 \%$ digestible, but individual AA digestibilities of microbes, and in particular bacteria, are not considered. Estimates of individual AA digest-

Received December 27, 2013.

Accepted March 6, 2014.

${ }^{1}$ Corresponding author: rdshaver@wisc.edu ibilities of rumen bacteria may improve predictions for absorbed metabolizable AA and help to improve N efficiency by dairy cows.

Estimates of AA digestibilities of microbes are difficult and expensive to collect in ruminant animals. Previous work has used duodenal- and ileal-cannulated animals sustained entirely on gastric infusions of VFA and micronutrients infused with large quantities of rumen microbes (Ørskov et al., 1979; Storm et al., 1983). Furthermore, common in vitro techniques to measure postruminal AA digestibility, such as the mobile bag technique (NRC, 2001) or the modified 3-step procedure (Gargallo et al., 2006), are not viable alternatives because microbes, with an average size of 1 to $2 \mu \mathrm{m}$, will wash out of the bags. The precision-fed cecectomized rooster bioassay is an alternative in vivo model to measure AA digestibilities and has been used to determine the intestinal digestibility of AA in duodenal digesta (Titgemeyer et al., 1990) and ruminally undegraded feed ingredients high in protein commonly fed to dairy cows (Aldrich et al., 1997; Boucher et al., 2009a,b). The objective of this experiment was to determine and assess the digestibility of AA in fluid- $(\mathbf{F A B})$ and particle-associated bacteria (PAB) collected from lactating dairy cows using the precision-fed cecectomized rooster bioassay.

Four ruminally cannulated multiparous lactating Holstein cows were used for the collection of rumen contents. Research was conducted at the University of Wisconsin-Madison Dairy Cattle Center under a protocol approved by the Institutional Animal Care and Use Committee of the University of Wisconsin-Madison. Rumen contents were collected from the anterior ventral sac near the reticulum using a $250-\mathrm{mL}$ bottle and were immediately placed on ice and transported back to the laboratory for isolation of bacteria by differential centrifugation (Whitehouse et al., 1994). Five hundredmilliliter rumen content samples were squeezed through 1 layer of cheesecloth. Solids retained on the cheesecloth were washed with $400 \mathrm{~mL}$ of $0.85 \%$ (wt/vol) $\mathrm{NaCl}$ solution and squeezed again. Filtrates were pooled and refrigerated at $5^{\circ} \mathrm{C}$ for less than $1 \mathrm{~h}$ until processed for 
isolation of FAB. The solids retained on the cheesecloth were transferred to a $500-\mathrm{mL}$ bottle containing $350 \mathrm{~mL}$ of cold solution containing $0.85 \%$ (wt/vol) $\mathrm{NaCl}$ and $0.1 \%$ (vol/vol) Tween-80, mixed thoroughly, and refrigerated at $5{ }^{\circ} \mathrm{C}$ overnight until processed for isolation of PAB. Filtrates for FAB isolation were centrifuged $\left(1,000 \times g\right.$ for $5 \mathrm{~min}$ at $\left.5^{\circ} \mathrm{C}\right)$. Pellets were added to the bottle contents containing $\mathrm{PAB}$, and supernatants were decanted and recentrifuged $(11,330 \times g$ for $30 \mathrm{~min}$ at $5^{\circ} \mathrm{C}$ ). These supernatants were discarded and the pellets were resuspended in $100 \mathrm{~mL}$ of saline solution and recentrifuged $\left(11,330 \times g\right.$ for $30 \mathrm{~min}$ at $\left.5^{\circ} \mathrm{C}\right)$. Supernatants were then discarded and the bottle containing FAB were stored at $-20^{\circ} \mathrm{C}$ until lyophilized. Contents of the PAB bottles were blended for $20 \mathrm{~s}$ in a 1-speed Waring blender (Waring Products Division, New Hartford, $\mathrm{CT}$ ), transferred back to the bottles and stored at $5^{\circ} \mathrm{C}$ overnight. Contents of PAB bottles were then squeezed through 2 layers of cheesecloth and the filtrates were centrifuged $\left(1,000 \times g\right.$ for $5 \mathrm{~min}$ at $\left.5^{\circ} \mathrm{C}\right)$. The pellets were discarded and the supernatant was recentrifuged $\left(11,330 \times g\right.$ for $30 \mathrm{~min}$ at $\left.5^{\circ} \mathrm{C}\right)$. Supernatants and final PAB pellets were processed the same as FAB. Bacterial samples were composited by $\mathrm{PAB}$ or FAB and ground through a 1-mm Wiley mill screen (Arthur H. Thomas Co., Swedesboro, NJ). All FAB and PAB collections were pooled to yield 1 sample per bacteria type.

Bacterial samples were analyzed for intestinal digestibility of AA using the precision-fed cecectomized rooster bioassay. The experiment was conducted under a protocol approved by the Institutional Animal Care and Use Committee of the University of Illinois (Urbana). The cecectomized rooster assay was conducted as described by Parsons (1985) and Aldrich et al. (1997). Thirteen grams of pooled FAB or PAB, ground through a 1-mm screen, were mixed with $13 \mathrm{~g}$ of ground corn, and the total $26 \mathrm{~g}$ of sample mixture were crop intubated to cecectomized Single Comb White Leghorn roosters. Four roosters received FAB and 5 roosters received PAB. An additional 4 roosters were crop intubated with $26 \mathrm{~g}$ of corn only so that AA digestibilities of the FAB and PAB could be calculated by difference. For crop intubation, the beak was opened and the stem of a funnel was inserted into the crop. Feed was withheld from the roosters for $24 \mathrm{~h}$ before and $48 \mathrm{~h}$ after intubation of samples, and the birds had ad libitum access to water. Roosters were housed individually in wire mesh cages fitted with excreta collection trays, and total excreta were collected for $48 \mathrm{~h}$ and lyophilized. Basal endogenous AA excretion was previously determined by 48 -h collection of excreta from fasted birds not used in this experiment according to Parsons (1985). Basal endogenous losses were used to calculate standardized FAB- and PAB-AA digestibilities, where standardized digestibility is defined as digestibility estimates calculated by subtracting only basal endogenous AA losses from the outflow of AA (Stein et al., 2007).

Intact bacterial samples, corn grain, and rooster excreta from birds fed only corn grain and corn grain plus FAB or PAB were sent to Experimental Station Chemical Laboratories (University of Missouri-Columbia) for analysis of AA content by cation-exchange HPLC coupled with postcolumn ninhydrin derivatization and quantitation (method 982.30; AOAC International, 2012). Samples of the TMR fed to the cows were collected once every 2 wk during the rumen fluid collection phase. Samples were dried in a forced-air oven at $60^{\circ} \mathrm{C}$ for $48 \mathrm{~h}$ to determine DM content, ground the same as the bacterial samples listed above, composited, and sent to Dairyland Laboratories Inc. (Arcadia, WI) for analysis. Samples of TMR, FAB, and PAB were analyzed for DM, OM (method 942.05; AOAC International, 2012), CP (method 990.03; AOAC International, 2012), ether extract (method 2003.05; AOAC International, 2012), and NDF using $\alpha$-amylase and sodium sulfite (Van Soest et al., 1991). The TMR was analyzed for starch according to Bach Knudsen, (1997; YSI Biochemistry Analyzer; YSI Inc., Yellow Springs, OH). The FAB and $\mathrm{PAB}$ were lysed using $\mathrm{NaOH}$ for analysis of glycogen according to Hall (2011).

Standardized AA digestibilities for FAB and PAB were calculated as follows: standardized AA digestibility $(\%)=(\{\mathrm{AA}$ intake $-[\mathrm{AA}$ output $-($ undigested AA from corn grain + basal endogenous AA)]\}/AA intake) $\times 100$. Data were analyzed as a completely randomized design using PROC MIXED of SAS (2004; SAS Institute Inc., Cary, NC). The model included the fixed effect of the bacteria sample and the random effect of the rooster within bacteria type. To determine differences among individual EAA digestibilities for either $\mathrm{FAB}$ or $\mathrm{PAB}$, the mean EAA digestibility was compared against individual EAA estimates using PROC MIXED and included the fixed effect of the AA digestibilities and the random effect of rooster within bacteria type. Means were determined using the least squares means statement. Statistical significance and trends were declared at $P \leq 0.05$ and $P>0.05$ to $P<$ 0.10 , respectively.

The ingredient and chemical composition of the TMR offered to the cannulated cows is listed in Table 1. The TMR contained $88.5 \%$ forage and may have reduced population diversity of FAB-specific microbes and increased the biomass of $\mathrm{PAB}$ relative to FAB. However, the majority of bacterial biomass in a typical lactating dairy cow diet is associated with the particle fraction. Martin and Michalet-Doreau (1995) found that $74 \%$ of total bacteria was PAB using ${ }^{15} \mathrm{~N}$ labeling and Mullins et al. (2013) determined that $92 \%$ of total bacterial 
Table 1. Ingredient and chemical composition (\% of DM, unless otherwise noted) of the TMR offered to the cows

\begin{tabular}{lc}
\hline Item & Amount \\
\hline Alfalfa silage & 44.5 \\
Corn silage & 26.8 \\
Alfalfa hay & 10.7 \\
Straw & 6.5 \\
Concentrate mix 1 & 11.5 \\
Nutrient composition & \\
DM, \% as fed & 47.4 \\
OM & 92.1 \\
CP & 14.7 \\
NDF & 46.1 \\
Starch & 10.6 \\
Ether extract & 3.4 \\
NFC & 28.6 \\
TDN & 82.1 \\
NE & Mcal $/ \mathrm{kg}$ \\
\hline
\end{tabular}

${ }^{1}$ Concentrate mix $=37.6 \%$ corn; $28.1 \%$ dried distillers grain plus solubles; $18.0 \%$ soybean meal; $9.0 \%$ corn gluten feed; $2.0 \%$ calcium carbonate; $1.8 \%$ soy hulls; $1.1 \%$ sodium bicarbonate; $0.7 \%$ salt; $0.4 \%$ vitamins $\mathrm{A}, \mathrm{D}$, and E; $0.4 \%$ monocalcium phosphate; $0.3 \%$ Dynamate (Mosaic Co., Plymouth, MN); $0.3 \%$ magnesium oxide; $0.2 \%$ trace mineral salt; and $0.2 \%$ biotin.

${ }^{2}$ Nonfiber carbohydrates $=100-(\mathrm{NDF}+\mathrm{CP}+$ ether extract + ash $)$.

DNA was associated with the particle fraction using real-time quantitative PCR.

The chemical and AA composition of FAB and PAB are listed in Table 2. The OM (\% of DM) was 83.2 and $87.4 \%$ for $\mathrm{FAB}$ and $\mathrm{PAB}$, respectively. In published literature, FAB comprised 62 to $85 \% \mathrm{OM}$ and $\mathrm{PAB}$ comprised 74 to $92 \%$ OM, whereas bacteria comprised 6 to $9 \% \mathrm{~N}$ (\% of DM; Hvelplund and Hesselholt, 1987; Rodríguez et al., 2000; Yang et al., 2001; Vicente et al., 2004 ), and total lipids ranged from 5 to $13 \%$ for $\mathrm{FAB}$ and 11 to $28 \%$ for PAB (Bauchart et al., 1990; Rodríguez et al., 2000; Vlaeminck et al., 2006). In the present experiment, the $\mathrm{N}$ and $\mathrm{OM}$ fractions are similar to other published studies, whereas the lipid fraction is reduced. Vlaeminck et al. (2006) determined that total lipids (\% of $\mathrm{DM}$ ) increased in $\mathrm{FAB}$ and $\mathrm{PAB}$ with decreasing dietary forage:concentrate levels. The high-forage diet fed in the present experiment may have resulted in the lower concentration of total lipids in rumen bacteria. The EAA composition of FAB and PAB is similar to values reported by Storm and Ørskov (1983) and Clark et al. (1992). The AA composition of rumen bacteria can vary substantially (Clark et al., 1992); however, it is unknown if changes to the AA or nutrient composition of rumen microbes can affect AA digestibility of the microbes. In addition, differences among studies in AA composition of rumen microbes may represent analytical issues related to AA quantification or bacterial isolation and not true differences among samples.

The AA digestibilities of FAB and PAB are listed in Table 3. The digestibility of total AA for FAB and
Table 2. Chemical and AA composition of fluid- (FAB) and particleassociated bacteria (PAB)

\begin{tabular}{lrr}
\hline Item $^{1}$ & FAB & PAB \\
\hline Nutrient composition, \% of DM & & \\
OM & 83.2 & 87.4 \\
N & 8.5 & 8.1 \\
TAA & 39.9 & 37.2 \\
Glycogen & 3.5 & 4.8 \\
Ether extract & 2.4 & 8.8 \\
AA composition, \% of TAA & & \\
Ala & 7.4 & 6.9 \\
Arg & 4.8 & 4.9 \\
Asp & 11.9 & 11.8 \\
Cys & 1.2 & 1.2 \\
Glu & 12.5 & 12.2 \\
Gly & 5.8 & 5.7 \\
His & 1.9 & 1.9 \\
Ile & 5.8 & 6.1 \\
Leu & 7.8 & 8.1 \\
Lys & 8.3 & 8.4 \\
Met & 2.4 & 2.3 \\
Ser & 3.9 & 3.6 \\
Phe & 5.1 & 5.4 \\
Pro & 3.8 & 3.9 \\
Thr & 5.3 & 5.1 \\
Trp & 1.0 & 1.1 \\
Tyr & 4.8 & 5.0 \\
Val & 6.4 & 6.4 \\
BCAA & 20.6 \\
EAA & & \\
NEAA & 48.8 & 49.7 \\
TA & 51.2 & 50.3 \\
\hline
\end{tabular}

${ }^{1} \mathrm{TAA}=$ total $\mathrm{AA} ; \mathrm{BCAA}=$ branched-chain $\mathrm{AA}$.

PAB were 76.8 and $75.5 \%$, respectively. These values are similar to the AA digestibility of microorganisms (80\%) reported in NRC (2001). A trend existed for a difference between FAB and PAB for Met digestibility $(P=0.08)$. Otherwise, no difference existed in digestibility between FAB and PAB. The AA digestibility results in the present study are greater than the estimates of apparent AA digestibility of rumen microorganisms determined in sheep $($ mean $=71 \%$; Armstrong and Hutton, 1975), and goats (mean $=57 \%$; Lee and Tasaki, 1977); however, apparent digestibilities will be lower than true digestibilities. Storm et al. (1983) determined the true digestibility of AA in sheep and found greater digestibility (82\%) compared with the present study. However, Storm et al. (1983) did not find any difference between AA in their digestibilities, except for diaminopimelic acid (DAPA), an AA component of bacterial cell walls. Furthermore, Tas et al. (1981) determined that true absorption of microbial AA was $87 \%$ in sheep, using multiple regression analysis, but this estimate did not include Cys, Trp, Pro, or DAPA, which are AA that typically have lower digestibilities. Hvelplund and Hesselholt (1987) found that true digestibility of AA in microbial protein varied between 80 to $91 \%$ in sheep. Intestinal digestibilities among individual AA was not significantly different; however, 
Table 3. Digestibility of amino acids in fluid- (FAB) and particleassociated bacteria (PAB) using the precision-fed cecectomized rooster bioassay

\begin{tabular}{lllcc}
\hline Item $^{1}$ & FAB & PAB & SEM & $P$-value \\
\hline Ala & $72.8^{*}$ & 70.8 & 2.79 & 0.62 \\
Arg & 82.4 & $80.1^{*}$ & 2.01 & 0.44 \\
Asp & 78.2 & 76.4 & 2.24 & 0.56 \\
Cys & 71.1 & 61.9 & 4.83 & 0.20 \\
Glu & 74.7 & 71.8 & 2.96 & 0.49 \\
His & $83.1^{*}$ & 75.2 & 3.60 & 0.14 \\
Ile & 79.2 & 76.3 & 1.78 & 0.28 \\
Leu & 78.2 & 74.7 & 2.39 & 0.31 \\
Lys & 79.6 & 78.4 & 2.28 & 0.73 \\
Met & $82.2^{*}$ & 76.5 & 2.07 & 0.08 \\
Phe & 78.3 & $74.1^{*}$ & 2.13 & 0.19 \\
Pro & 74.3 & 73.6 & 2.64 & 0.85 \\
Ser & 71.2 & 65.3 & 4.22 & 0.34 \\
Thr & 75.7 & 72.8 & 3.47 & 0.56 \\
Trp & $76.2^{*}$ & 76.2 & 2.68 & 0.98 \\
Tyr & 76.5 & 75.1 & 2.33 & 0.69 \\
Val & $72.4^{*}$ & $70.9^{*}$ & 3.12 & 0.73 \\
BCAA & 76.6 & 75.9 & 2.20 & 0.81 \\
EAA & 78.7 & 75.5 & 2.36 & 0.35 \\
NEAA & 74.1 & 72.7 & 2.73 & 0.71 \\
TAA & 76.8 & 75.5 & 2.41 & 0.70 \\
\hline
\end{tabular}

${ }^{1} \mathrm{BCAA}=$ branched-chained $\mathrm{AA} ; \mathrm{TAA}=$ total $\mathrm{AA}$.

*Least squares EAA means within the same column differed $(P<$ 0.05) from the mean EAA.

DAPA (40\%), Phe (69\%), and Cys (74\%), exhibited lower digestibilities than the other AA.

Differences existed among AA when compared with the mean EAA value within bacteria type (Table 3 ). Arginine, His, and Met yielded greater digestibilities than the mean EAA in FAB, whereas Trp and Val digestibilities were lower. Arginine and Lys were greater than the mean EAA in PAB, whereas Phe and Val were lower. Storm et al. (1983) found the digestibility of $\operatorname{Arg}(89 \%)$ to be greater and His (68\%) to be lower than the mean total AA digestibility in microbial protein, whereas Hvelplund and Hesselholt (1987) found greater digestibilities for $\operatorname{Arg}(91 \%)$ and His (89\%), and a lower digestibility for Phe $(69 \%)$ in microbial protein. Digestibility of Met has also been found to be greater compared with total AA in some (Armstrong and Hutton, 1975; Lee and Tasaki, 1977), but not all studies (Storm et al., 1983; Hvelplund and Hesselholt, 1987).

In conclusion, based on mean total AA and EAA digestibilities in bacteria relative to NRC (2001) and previous research, the precision-fed cecectomized rooster bioassay appears to be a viable in vivo model for the determination of AA digestibilities in rumen bacteria. No difference existed in AA digestibilities between FAB and $\mathrm{PAB}$, but differences among AA digestibilities within bacterial type exist. Future research using the cecectomized rooster bioassay may allow for measurements of AA digestibilities of other rumen microorganisms such as protozoa.

\section{ACKNOWLEDGMENTS}

The authors thank Mike Peters and the staff at the University of Wisconsin Dairy Cattle Center (Madison) for care and feeding of the cows used in the trial.

\section{REFERENCES}

Aldrich, C. G., N. R. Merchen, C. M. Parsons, H. S. Hussein, S. Ingram, and J. R. Clodfelter. 1997. Assessment of postruminal amino acid digestibility of roasted and extruded whole soybeans with the precision-fed rooster assay. J. Anim. Sci. 75:3046-3051.

AOAC International. 2012. Official Methods of Analysis. 19th ed. AOAC International, Arlington, VA.

Armstrong, D. G., and J. B. Hutton. 1975. Fate of nitrogenous compounds entering the small intestine. Pages 432-447 in Digestion and Metabolism in the Ruminant. I. W. McDonald and A. C. I. Warner, ed. University of New England Publishing Unit, Armidale, Australia.

Bach Knudsen, K. E. 1997. Carbohydrate and lignin contents of plant materials used in animal feeding. Anim. Feed Sci. Technol. $67: 319-338$

Bauchart, D., F. Legay-Carmier, M. Doreau, and B. Gaillard. 1990. Lipid metabolism of liquid-associated and solid-adherent bacteria in rumen contents of dairy cows offered lipid-supplemented diets. Br. J. Nutr. 63:563-578.

Boucher, S. E., S. Calsamiglia, C. M. Parsons, H. H. Stein, M. D. Stern, P. S. Erickson, P. L. Utterback, and C. G. Schwab. 2009a. Intestinal digestibility of amino acids in rumen undegradable protein estimated using a precision-fed cecectomized rooster bioassay: I. Soybean meal and SoyPlus. J. Dairy Sci. 92:4489-4498.

Boucher, S. E., S. Calsamiglia, C. M. Parsons, H. H. Stein, M. D Stern, P. S. Erickson, P. L. Utterback, and C. G. Schwab. 2009b. Intestinal digestibility of amino acids in rumen-undegraded protein estimated using a precision-fed cecectomized rooster bioassay: II. Distillers dried grains with solubles and fish meal. J. Dairy Sci. 92:6056-6067.

Clark, J. H., T. H. Klusmeyer, and M. R. Cameron. 1992. Microbial protein synthesis and flows of nitrogen fractions to the duodenum of dairy cows. J. Dairy Sci. 75:2304-2323.

Gargallo, S., C. Calsamiglia, and A. Ferret. 2006. Technical note: A modified three-step in vitro procedure to determine intestinal digestion of proteins. J. Anim. Sci. 84:2163-2167.

Hall, M. B. 2011. Isotrichid protozoa influence conversion of glucose to glycogen and other microbial products. J. Dairy Sci. 94:45894602.

Hvelplund, T., and M. Hesselholt. 1987. Digestibility of individual amino acids in rumen microbial protein and undegraded dietary protein in the small intestine of sheep. Acta Agric. Scand. $37: 469-477$.

Lee, K.-S., and I. Tasaki. 1977. Effects of methionine supplementation on amino acid concentration of intestinal digesta and on its absorption from the small intestine in goats fed a urea diet. Jpn. J. Zootech. Sci. 48:474-480.

Martin, C., and B. Michalet-Doreau. 1995. Variations in mass and enzyme activity of rumen microorganisms: Effect of barley and buffer supplements. J. Sci. Food Agric. 67:407-413.

Mullins, C. R., L. K. Mamedova, A. J. Carpenter, Y. Ying, M. S. Allen, I. Yoon, and B. J. Bradford. 2013. Analysis of rumen microbial populations in lactating dairy cattle fed diets varying in carbohydrate profiles and Saccharomyces cerevisiae fermentation product. J. Dairy Sci. 96:5872-5881.

NRC. 2001. Nutrient Requirements of Dairy Cattle. 7th rev. ed. Natl. Acad. Sci., Washington, DC

Ørskov, E. R., D. A. Grubb, and J. S. Smith. 1979. Efficiency of utilization of volatile fatty acids for maintenance and energy retention by sheep. Br. J. Nutr. 41:541-551.

Parsons, C. M. 1985. Influence of caecectomy on digestibility of amino acids by roosters fed distillers' dried grains with solubles. J. Agric. Sci. 104:469-472. 
Rodríguez, C. A., J. González, M. R. Alvir, J. L. Repetto, C. Centeno, and F. Lamrani. 2000. Composition of bacteria harvested from the liquid and solid fractions of the rumen of sheep as influenced by feed intake. Br. J. Nutr. 84:369-376.

Stein, H. H., B. Sève, M. F. Fuller, P. J. Moughan, and C. F. M. de Lange. 2007. Invited review: Amino acid bioavailability and digestibility in pig feed ingredients: Terminology and application. J. Anim. Sci. 85:172-180.

Storm, E., D. S. Brown, and E. R. Ørskov. 1983. The nutritive value of rumen micro-organisms in ruminants. 3. The digestion of microbial and nucleic acids in, and losses of endogenous nitrogen from, the small intestine of the sheep. Br. J. Nutr. 50:479-485.

Storm, E., and E. R. Ørskov. 1983. The nutritive value of rumen microorganisms in ruminants. 1. Large-scale isolation and chemical composition of rumen micro-organisms. Br. J. Nutr. 50:463-470.

Tas, M. V., R. A. Evans, and R. F. E. Axford. 1981. The digestibility of amino acids in the small intestine of the sheep. Br. J. Nutr. 45:167-174.

Titgemeyer, E., N. Merchen, Y. Han, C. Parsons, and D. Baker. 1990. Assessment of intestinal amino acid availability in cattle by use of the precision-fed cecectomized rooster assay. J. Dairy Sci. 73:690-693.
Van Soest, P. J., F. B. Robertson, and B. A. Lewis. 1991. Methods for dietary fiber, neutral detergent fiber, and nonstarch polysaccharides in relation to animal nutrition. J. Dairy Sci. 74:3583-3597.

Vicente, F., J. A. Guada, J. Surra, J. Balcells, and C. Castrillo. 2004. Microbial contribution to duodenal purine flow in fattening cattle given concentrate diets, estimated by purine $\mathrm{N}$ labelling $\left({ }^{15} \mathrm{~N}\right)$ of different microbial fractions. Anim. Sci. 78:159-167.

Vlaeminck, B., V. Fievez, D. Demeyer, and R. J. Dewhurst. 2006. Effect of forage:concentrate ratio on fatty acid composition of rumen bacteria isolated from ruminal and duodenal digesta. J. Dairy Sci. $89: 2668-2678$.

Whitehouse, N. L., V. M. Olson, C. G. Schwab, W. R. Chesbro, K. D. Cunningham, and T. Lykos. 1994. Improved techniques for dissociating particle-associated mixed ruminal microorganisms from ruminal digesta solids. J. Anim. Sci. 72:1335-1343.

Yang, W. Z., K. A. Beauchemin, and L. M. Rode. 2001. Effect of dietary factors on distribution and chemical composition of liquid- or solid-associated bacterial populations in the rumen of dairy cows. J. Anim. Sci. 79:2736-2746. 